Article

\title{
Inclusion of Zinc Oxide Nanoparticles into Virus-Like Peptide Nanocapsules Self-Assembled from Viral $\beta$-Annulus Peptide
}

\section{Seiya Fujita and Kazunori Matsuura *}

Department of Chemistry and Biotechnology, Graduate School of Engineering, Tottori University, Koyama-minami 4-101, Tottori 680-8552, Japan; E-Mail: saint_arrow1208@yahoo.co.jp

* Author to whom correspondence should be addressed; E-Mail: ma2ra-k@chem.tottori-u.ac.jp; Tel.: +81-857-31-5262; Fax: +81-857-31-6729.

Received: 24 June 2014; in revised form: 22 August 2014 / Accepted: 25 August 2014 / Published: 2 September 2014

\begin{abstract}
A viral $\beta$-annulus peptide connected with a zinc oxide ( $\mathrm{ZnO}$ )-binding sequence (HCVAHR) at its N-terminal was synthesized, and the inclusion behavior of quantum-sized $\mathrm{ZnO}$ nanoparticles into the peptide nanocapsules formed by self-assembly of the peptide in water was investigated. Dynamic light scattering (DLS) measurements showed that ZnO nanoparticles (approximately $10 \mathrm{~nm})$ in the presence of the peptide $(0.1 \mathrm{mM})$ formed assemblies with an average size of $48 \pm 24 \mathrm{~nm}$, whereas $\mathrm{ZnO}$ nanoparticles in the absence of the peptide formed large aggregates. Transmission electron microscopy (TEM) observations of the $\mathrm{ZnO}$ nanoparticles in the presence of the peptide revealed that $\mathrm{ZnO}$ nanoparticles were encapsulated into the peptide nanocapsules with a size of approximately $50 \mathrm{~nm}$. Fluorescence spectra of a mixture of the peptide and $\mathrm{ZnO}$ nanoparticles suggested that the $\mathrm{ZnO}$ surface and the peptide interact. Template synthesis of $\mathrm{ZnO}$ nanoparticles with the peptide nanocapsules afforded larger nanoparticles (approximately $40 \mathrm{~nm}$ ), which are not quantum-sized $\mathrm{ZnO}$.
\end{abstract}

Keywords: self-assembly; $\beta$-annulus peptide; nanocapsule; $\mathrm{ZnO}$ nanoparticle; inclusion

\section{Introduction}

Nanometer-sized metals, semiconductors and metal oxides have attracted much attention owing to their peculiar physical and chemical properties compared to those of bulk materials [1,2]. Semiconductor nanoparticles (quantum dots), which are a topic of particular interest, are fluorescent 
nanoparticles that have advantages in brightness and stability and have consequently been applied as bioimaging materials [3-6]. CdSe nanoparticles, which are representative semiconductor quantum dots, are known to exhibit significant toxicity [7]. In contrast, zinc oxide $(\mathrm{ZnO})$ nanoparticles are known to be less toxic fluorescent quantum dots, whose fluorescent color varies depending on their size and surface defects [8-10]. However, the fluorescence of $\mathrm{ZnO}$ nanoparticles is unstable in water, because the nanoparticles aggregate. However, the application of silica [11] and polymer [12] coatings to the surface of $\mathrm{ZnO}$ nanoparticles improved their stability in water, and the resulting coated $\mathrm{ZnO}$ nanoparticles have been used in cell imaging [13].

Ferritin is a natural cage-like protein that performs important roles as a nanocontainer for the storage of ferrous ions [14-16]. Because the inside of apo-ferritin is regarded as a nanospace with a diameter of $7 \mathrm{~nm}$, various inorganic nanomaterials, such as metals [17-20] and semiconductor nanoparticles [21-27], have been synthesized inside the hollow interior of apo-ferritin. The inorganic nanomaterials are stabilized by being protected by the protein cage. Spherical viruses are another natural protein cage, comprising genome nucleic acids encapsulated in an outer protein shell known as a capsid [28]. Since the viral capsids are an icosahedral protein assembly with discrete nanospace, they have attracted extensive attention as a novel nanocarrier and nanoreactor [29-32]. To date, the encapsulation of guest nanomaterials, such as dyes [33,34], drugs [35], proteins [36,37], polymers [38], gold nanoparticles [39-41], iron oxide nanoparticles [42] and quantum dots [43,44], instead of genome nucleic acids into spherical viral capsids has been reported.

Recently, chemical strategies to rationally design artificial peptide and protein assemblies have been developed $[45,46]$. We have observed that the synthetic 24-mer $\beta$-annulus peptide fragment (INHVGGTGGAIMAPVAVTRQLVGS), which participates in the formation of the dodecahedral internal skeleton, spontaneously self-assembles into virus-like nanocapsules in water $[47,48]$. We have demonstrated that the interior of virus-like peptide nanocapsules might be cationic at neutral $\mathrm{pH}$ and have encapsulated anionic dyes and DNA in the nanocapsules [49]. The $\mathrm{pH}$ dependence of the $\xi$-potentials of the nanocapsules suggests that the C-terminal is directed toward the surface, whereas the N-terminal is directed toward the interior of the peptide nanocapsules. Therefore, the virus-like peptide nanocapsule can be decorated with various functional groups through modification of the peptide's terminals.

Herein, we designed a novel $\beta$-annulus peptide connected via a ZnO-binding sequence at the $\mathrm{N}$-terminal, which is directed toward the interior of the peptide nanocapsules. To date, several ZnO-binding peptides have been developed by the screening of peptide libraries [50-53]. We employed the HCVAHR sequence, developed by Okochi et al. [54], as the ZnO-binding peptide, because this short peptide exhibits the highest affinity toward $\mathrm{ZnO}$ among the reported ZnO-binding peptides [55]. In this paper, we report the behavior related to the inclusion of $\mathrm{ZnO}$ nanoparticles into the virus-like nanocapsules self-assembled from 33-mer ZnO-binding $\beta$-annulus peptide 1 (Figure 1). 
Figure 1. Schematic illustration of the inclusion of $\mathrm{ZnO}$ nanoparticles in nanocapsules self-assembled from $\mathrm{ZnO}$-binding $\beta$-annulus peptide.

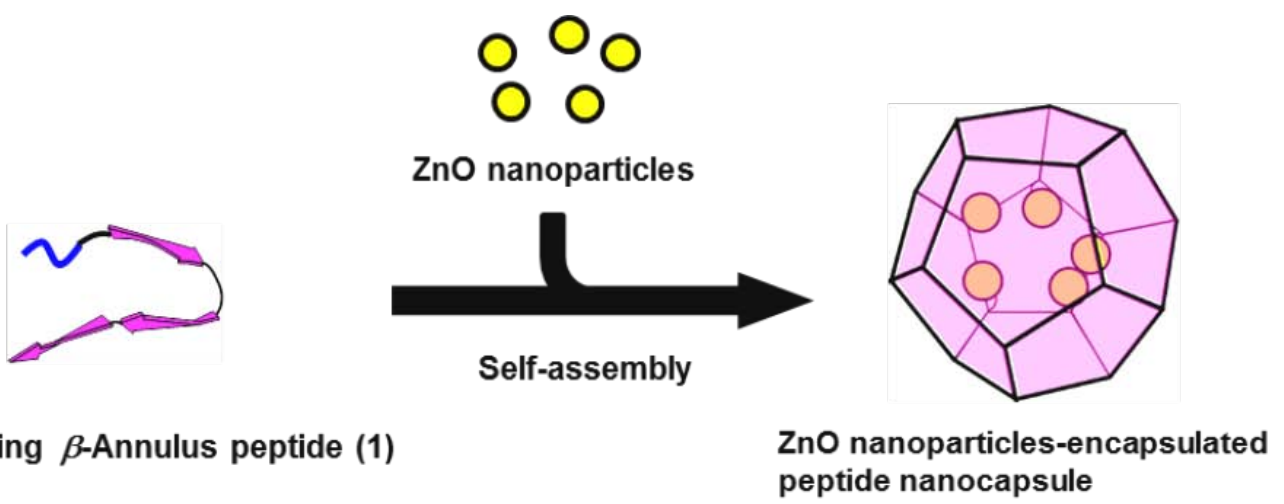

\author{
peptide (1) : HCVAHRGGGINHVGGTGGAIMAPVAVTRQLVGS \\ peptide (2) : INHVGGTGGAIMAPVAVTRQLVGS \\ peptide (3) : HCVAHRGGG
}

\title{
2. Results and Discussion
}

\subsection{Synthesis and Self-Assembly of ZnO-Binding $\beta$-Annulus Peptide}

The 33-mer ZnO-binding $\beta$-annulus peptide 1 (HCVAHRGGGINHVGGTGGAIMAPVAVTRQLVGS), whose $\beta$-annulus and HCVAHR sequence are linked with a GGG spacer, 24-mer $\beta$-annulus peptide 2 and 9-mer ZnO-binding peptide 3 (HCVAHRGGG) were synthesized via the Fmoc-protected solid-phase method using (1-cyano-2-ethoxy-2-oxoethylidenaminooxy)dimethylamino-morpholino-carbenium hexafluorophosphate (COMU) as a condensation reagent; the resulting peptide were purified by reverse-phase HPLC (high performance liquid chromatography) and subsequently confirmed by MALDI-TOF-MS (matrix assisted laser desorption ionization time-of flight mass spectrometry).

ZnO-binding $\beta$-annulus peptide 1 was dissolved in $10 \mathrm{mM}$ Tris-HCl buffer ( $\mathrm{pH} \mathrm{7.4)} \mathrm{without}$ heating. The self-assembling behavior of peptide $\mathbf{1}$ in the buffer was investigated by dynamic light scattering (DLS) measurements and transmission electron microscopy (TEM) observations. The DLS of $1.0 \mathrm{mM}$ peptide 1 in the buffer indicated the formation of assemblies with a size of $36 \pm 17 \mathrm{~nm}$ (Figure 2a), which is comparable to the size (37 $\pm 10 \mathrm{~nm}$ ) of peptide nanocapsules self-assembled from unmodified $\beta$-annulus peptide 2 at $1.0 \mathrm{mM}$ [47]. The TEM image stained with sodium phosphotungstate also showed the existence of $30-50 \mathrm{~nm}$ spherical assemblies (Figure 2c). In contrast, at $0.1 \mathrm{mM}$ peptide 1, the DLS revealed a multi-dispersed size distribution (Figure 2b), and the TEM image indicated the existence of irregular fibrous assemblies (Figure $2 \mathrm{~d}$ ). These results indicate that peptide $\mathbf{1}$ at $1.0 \mathrm{mM}$ self-assembled into the peptide nanocapsules, whereas the nanocapsules were unstable at $0.1 \mathrm{mM}$. Because $\beta$-annulus peptide 2 could form stable nanocapsules at a concentration greater than $25 \mu \mathrm{M}$ [47], the additional HCVAHRGGG sequence clearly made the nanocapsules unstable. 
Figure 2. Size distribution obtained from DLS (a,b) and TEM images (c,d) for aqueous solutions of peptide 1 at $1.0 \mathrm{mM}(\mathbf{a}, \mathbf{c})$ and $0.1 \mathrm{mM}(\mathbf{b}, \mathbf{d})$ in $10 \mathrm{mM}$ Tris-HCl buffer (pH 7.4) at $25^{\circ} \mathrm{C}$. The TEM samples were stained with sodium phosphotungstate.

a

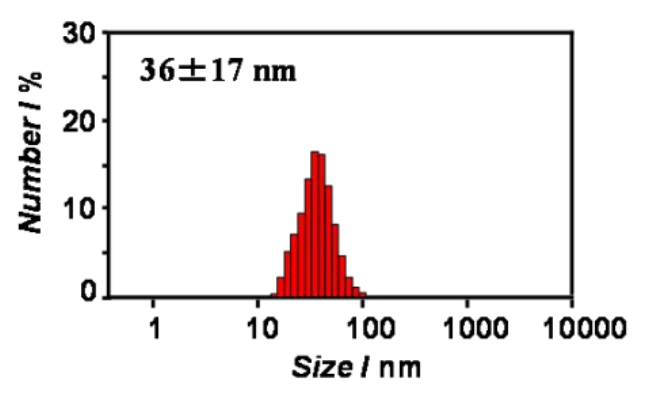

b

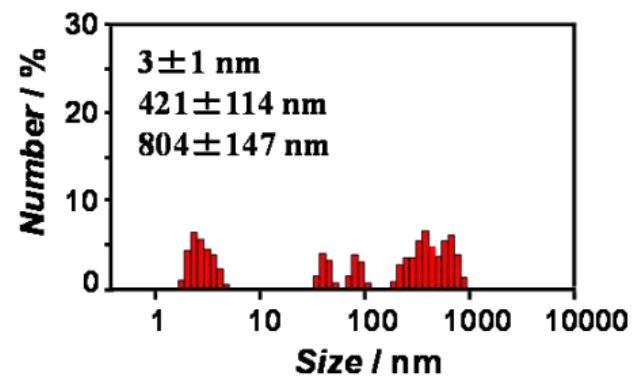

C

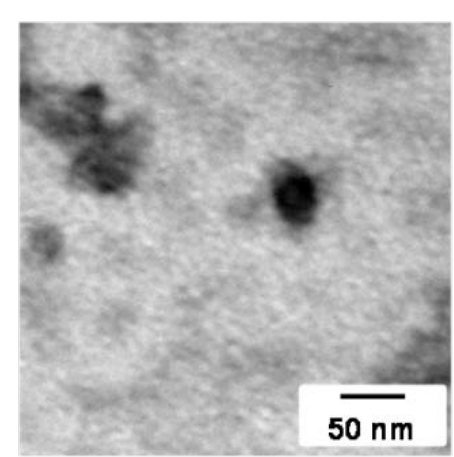

d

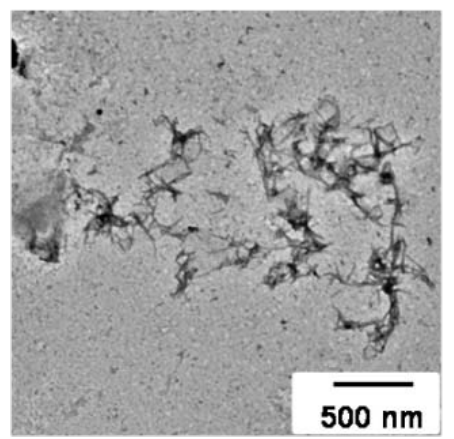

\subsection{Preparation and UV-Vis Spectra of ZnO Nanoparticles}

$\mathrm{ZnO}$ nanoparticles were prepared from $\mathrm{Zn}(\mathrm{OH})_{2}$ according to a literature method reported by Uekawa et al. [56]. The UV-Vis spectrum of the synthesized ZnO nanoparticles in $10 \mathrm{mM}$ Tris-HCl buffer showed a cliff-shaped spectrum with an absorption peak at $340 \mathrm{~nm}$ (Figure 3, black), indicating the formation of $\mathrm{ZnO}$ nanoparticles of a quantum size. Meulenkamp reported an experimental Equation (1) of size dependence of the optical band-gap of $\mathrm{ZnO}$ nanoparticles, where $d$ is the diameter of $\mathrm{ZnO}$ nanoparticles and $\lambda_{1 / 2}$ is the wavelength at which the absorption is $50 \%$ of that at the excitonic peak [57]:

$$
1240 \lambda_{1 / 2}=3.556+799.9 / d^{2}-22.64 / d
$$

According to the spectrum, $\lambda_{1 / 2}$ was $363 \mathrm{~nm}$; thus, the diameter of the $\mathrm{ZnO}$ nanoparticles was calculated to be $5.6 \mathrm{~nm}$. However, a gentle-sloping absorption occurred in the wavelength regions longer than $390 \mathrm{~nm}$; thus, the band edge was obscured, indicating coexistence of larger $\mathrm{ZnO}$ nanoparticles. The addition of peptides 1-3 into the dispersion of $\mathrm{ZnO}$ nanoparticles minimally affected the nanoparticles' UV-Vis spectra (Figure 3). 
Figure 3. UV-Vis spectra of (black) $\mathrm{ZnO}$ nanoparticles, (blue) a mixture of $\mathrm{ZnO}$ nanoparticles and peptide $\mathbf{1}$, (red) a mixture of $\mathrm{ZnO}$ nanoparticles and peptide $\mathbf{2}$, and (green) a mixture of $\mathrm{ZnO}$ nanoparticles and peptide 3 at $[\mathrm{ZnO}]=0.1 \mathrm{mM}$ and [peptide] $=0.1 \mathrm{mM}$ in $10 \mathrm{mM}$ Tris-HCl buffer ( $\mathrm{pH} 7.4)$ at $25^{\circ} \mathrm{C}$.

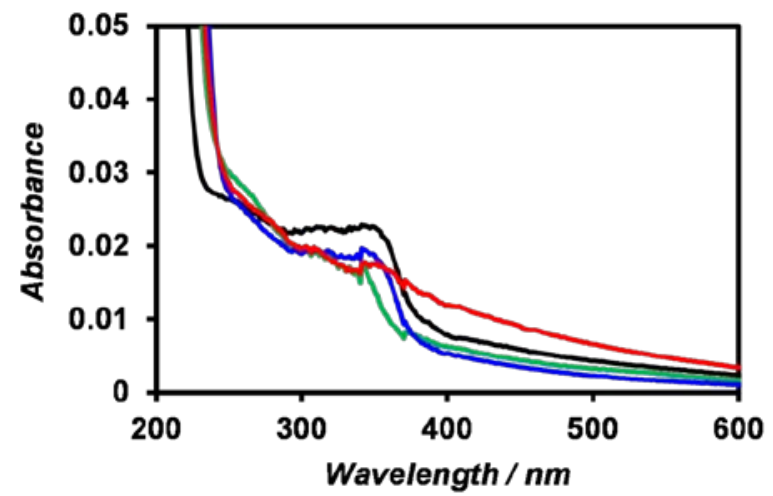

\subsection{Inclusion of $\mathrm{ZnO}$ Nanoparticles into Peptide Nanocapsules}

The DLS results for the synthesized $\mathrm{ZnO}$ nanoparticles $([\mathrm{ZnO}]=0.1 \mathrm{mM})$ in $10 \mathrm{mM}$ Tris-HCl buffer showed the formation of aggregates of $841 \pm 222 \mathrm{~nm}$ (Figure 4a). The TEM also showed the formation of large aggregates consisting of $\mathrm{ZnO}$ nanoparticles with diameter of 9-15 nm (Figure 4b). These results suggest that the synthesized $\mathrm{ZnO}$ nanoparticles were unstable against aggregation in the buffer. The ZnO nanoparticles observed by TEM were larger than the size estimated on the basis of the UV-Vis spectrum, which might indicate that the indistinct band edge results in the underestimation of the nanoparticles’ size.

Figure 4. Size distribution obtained from (a) DLS and (b) unstained TEM image of ZnO nanoparticles $([\mathrm{ZnO}]=0.1 \mathrm{mM})$ in $10 \mathrm{mM}$ Tris-HCl buffer $(\mathrm{pH} 7.4)$ at $25{ }^{\circ} \mathrm{C}$.
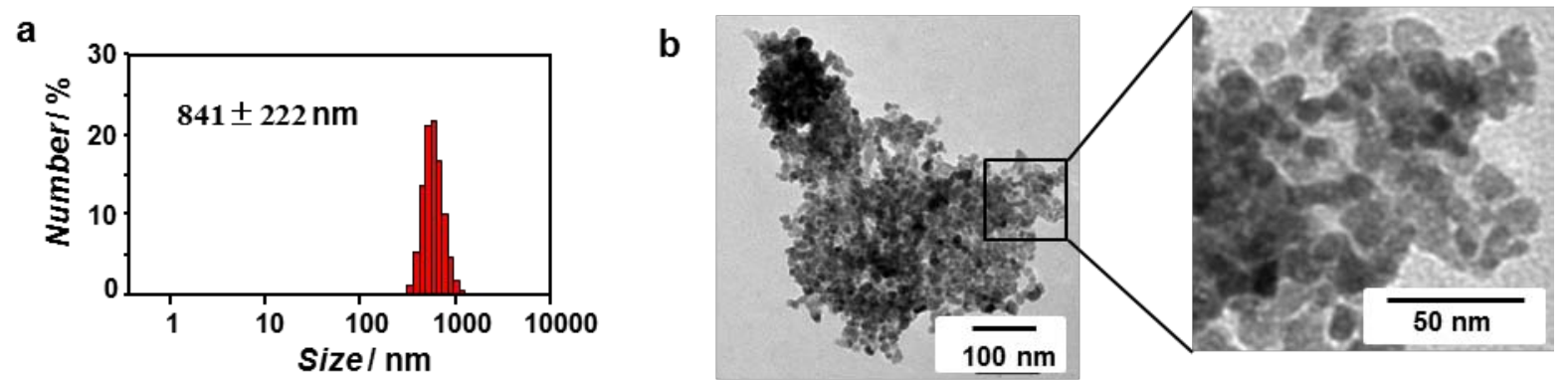

The inclusion behavior of $\mathrm{ZnO}$ nanoparticles into peptide nanocapsules formed by self-assembly of the $\mathrm{ZnO}$-binding $\beta$-annulus peptide $\mathbf{1}$ in water was investigated by DLS and TEM. An aqueous dispersion of $\mathrm{ZnO}$ nanoparticles in $10 \mathrm{mM}$ Tris- $\mathrm{HCl}$ buffer ( $\mathrm{pH} 7.4$ ) was added to the dried peptide 1 (the final concentration: $[\mathrm{ZnO}]=$ [peptide] $=0.1 \mathrm{mM}$ ), and the mixture was subsequently incubated for $10 \mathrm{~min}$ at room temperature. Figure 5a,d shows the size distribution obtained from DLS and TEM images, respectively, of a mixture of $\mathrm{ZnO}$ nanoparticles and $\mathrm{ZnO}$-binding $\beta$-annulus peptide $\mathbf{1}$. Assemblies consisting of several $\mathrm{ZnO}$ nanoparticles (individual size: approximately $10 \mathrm{~nm}$ ) with an average diameter of $48 \pm 24 \mathrm{~nm}$ were observed without the presence of large aggregates in Figure 4 . The diameter is comparable to that of peptide nanocapsules self-assembled from $\beta$-annulus peptide 2 [47]. 
These results indicate that several $\mathrm{ZnO}$ nanoparticles with a size of approximately $10 \mathrm{~nm}$ are included into the peptide nanocapsules self-assembled from peptide $\mathbf{1}$. Because peptide $\mathbf{1}$ did not form nanocapsules at $0.1 \mathrm{mM}$, as shown in Figure $2 \mathrm{~b}$, the peptide nanocapsules were apparently stabilized by the presence of the $\mathrm{ZnO}$ nanoparticles. It is probable that the $\mathrm{ZnO}$-encapsulated peptide nanocapsules formed by the following mechanism: (1) the ZnO-binding sequence HCVAHR of peptide 1 was adsorbed onto $\mathrm{ZnO}$ nanoparticles; (2) several $\mathrm{ZnO}$ nanoparticles were aggregated; and (3) simultaneously the $\beta$-annulus sequence of peptide $\mathbf{1}$ formed nanocapsule on aggregates of $\mathrm{ZnO}$ nanoparticles. In contrast, a mixture of $\mathrm{ZnO}$ nanoparticles and $\beta$-annulus peptide 2, which lacks the ZnO-binding sequence, formed larger and irregular aggregates (Figure 5e), although the average diameter obtained from DLS was $53 \pm 29 \mathrm{~nm}$ (Figure 5b). In addition, a mixture of $\mathrm{ZnO}$ nanoparticles and $\mathrm{ZnO}$-binding peptide $\mathbf{3}$ also formed larger and irregular aggregates (Figure 5f). These results indicate that the formation of 50 -nm assemblies consisting of several $\mathrm{ZnO}$ nanoparticles is characteristic for $\mathrm{ZnO}$-binding $\beta$-annulus peptide 1. The $\mathrm{ZnO}$ nanoparticles likely interact with the $\mathrm{ZnO}$-binding sequence in the peptide nanocapsules self-assembled from peptide 1. The $\mathrm{ZnO}$ nanoparticles encapsulated in nanocapsules self-assembled from peptide 1 remained dispersed for at least five hours, whereas the $\mathrm{ZnO}$ nanoparticles in the presence of peptide 2 or 3 aggregated within 10 min.

Figure 5. Size distribution obtained from DLS (a-c) and unstained TEM images (d-f) of $\mathrm{ZnO}$ nanoparticles in the presence of peptides $([\mathrm{ZnO}]=$ [peptide $]=0.1 \mathrm{mM}) .(\mathbf{a}, \mathbf{d})$ Mixture of $\mathrm{ZnO}$ nanoparticles and peptide 1; (b,e) mixture of nanoparticles and peptide 2; and (c,f) mixture of $\mathrm{ZnO}$ nanoparticles and peptide 3 in $10 \mathrm{mM}$ Tris- $\mathrm{HCl}$ buffer (pH 7.4) at $25{ }^{\circ} \mathrm{C}$.

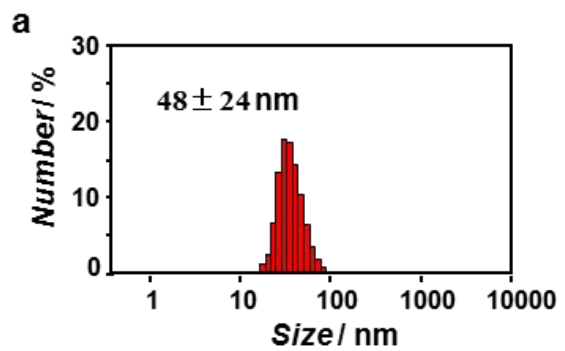

b

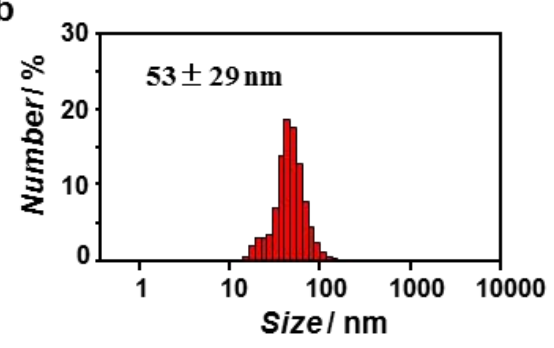

C

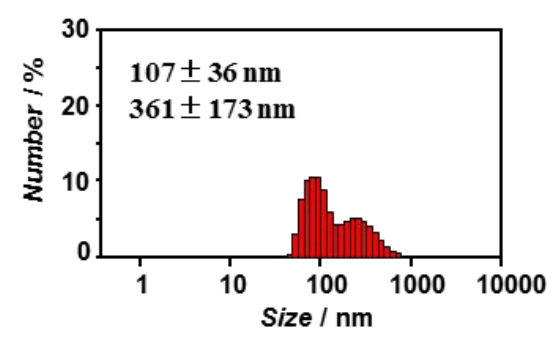

d

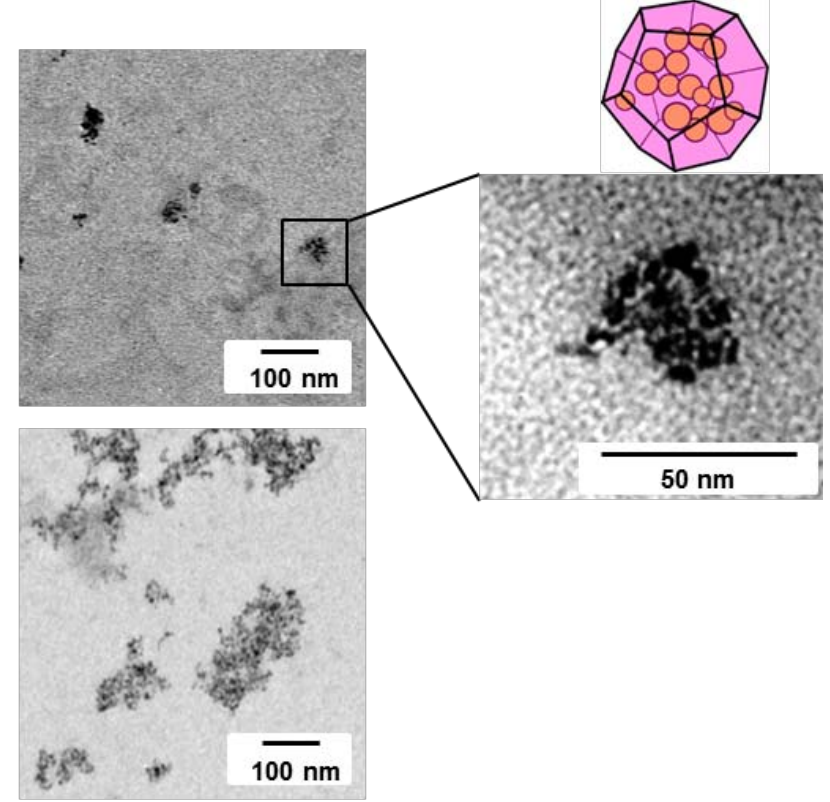

f

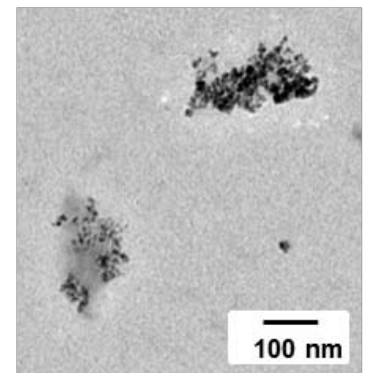


As shown in Figure 2a, peptide 1 forms nanocapsules with a size of $36 \pm 17 \mathrm{~nm}$ at $1.0 \mathrm{mM}$. Therefore, we examined the templated synthesis of $\mathrm{ZnO}$ nanoparticles using $\mathrm{ZnO}$-binding $\beta$-annulus peptide 1 at $1.0 \mathrm{mM}$. When $\mathrm{Zn}(\mathrm{OH})_{2}$ was dehydrated in the presence of $1.0 \mathrm{mM}$ peptide $\mathbf{1}$, $\mathrm{ZnO}$ nanoparticles with a size of approximately $40 \mathrm{~nm}$ were observed by DLS and TEM (Figure 6a,d), which indicates that peptide $\mathbf{1}$ acted as a template in $\mathrm{ZnO}$ formation. On the other hand, syntheses of $\mathrm{ZnO}$ nanoparticles in the presence of peptides $\mathbf{2}$ and $\mathbf{3}$ afforded irregular particles with a size of 200-1000 nm. However, the UV-Vis spectrum of the ZnO nanoparticles synthesized in the presence of peptide 1 was characteristic of bulk $\mathrm{ZnO}$ (Figure 6g).

Figure 6. Size distribution obtained from DLS (a-c), unstained TEM image (d-f), and $\mathrm{UV}-\mathrm{Vis}$ spectrum (g) of $\mathrm{ZnO}$ nanoparticles synthesized in the presence of peptide $\mathbf{1}$ (a,d,g), peptide 2 (b,e), and peptide 3 (c,f) in water.

a

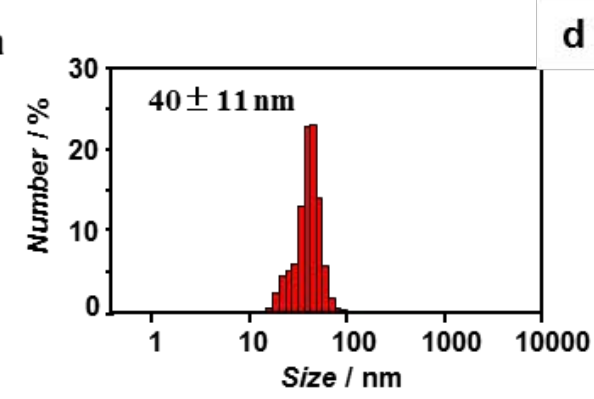

b
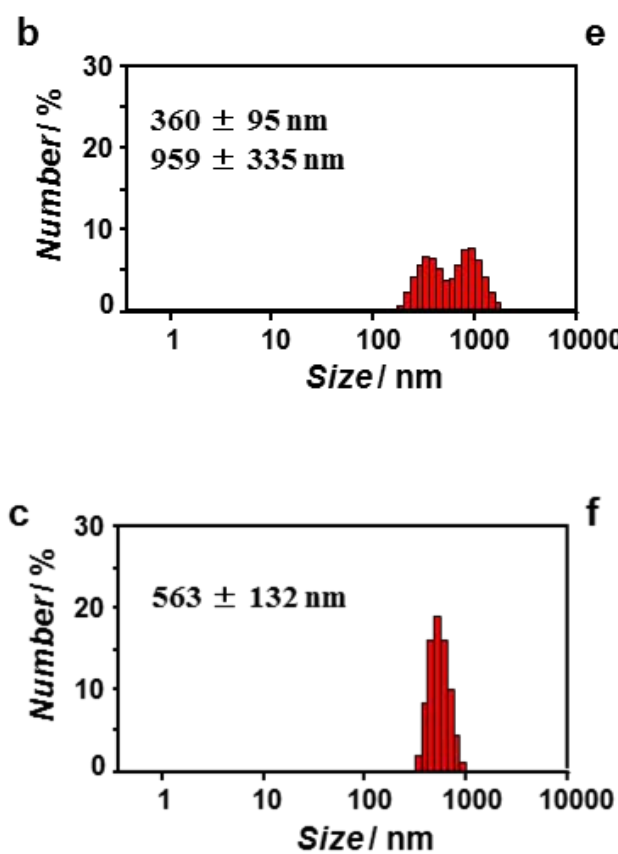
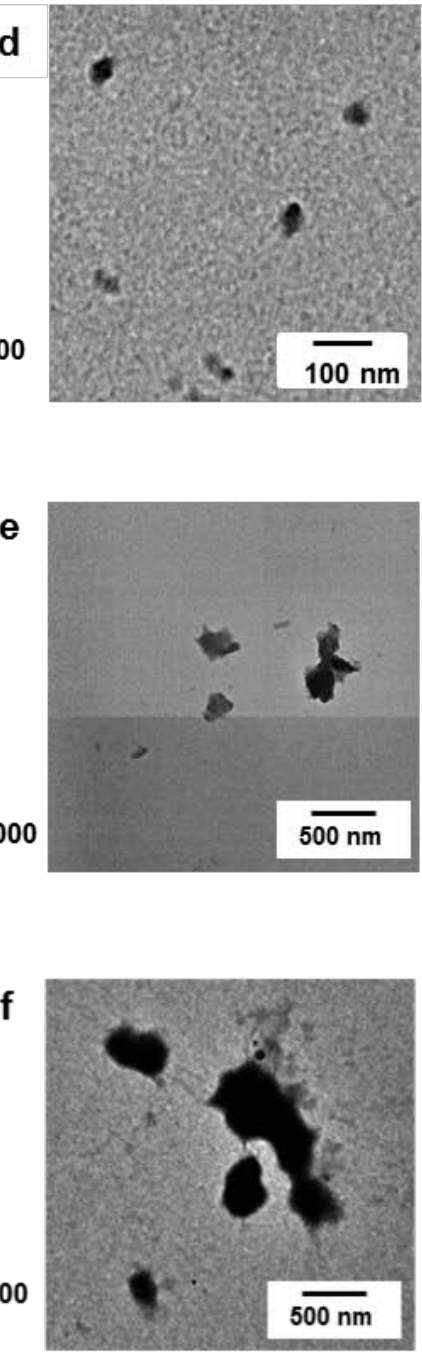

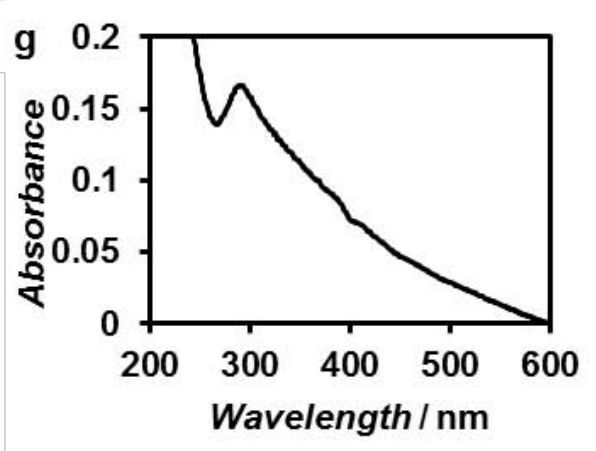

Wavelength / $\mathrm{nm}$

\subsection{Fluorescence Spectra of ZnO Nanoparticles Included in Peptide Nanocapsule}

The fluorescence spectrum of $\mathrm{ZnO}$ nanoparticles excited at $340 \mathrm{~nm}$ in Tris-HCl buffer showed three emission peaks (Figure 7, black): near-UV emission at $380 \mathrm{~nm}$, which originates from the near-band-edge transition [58]; blue-violet emission at $415 \mathrm{~nm}$, which originates from zinc interstitial defects [58]; and green emission at $540 \mathrm{~nm}$, which originates from the recombination of electrons trapped at 
singly-ionized oxygen-vacancy defects [59]. The fluorescence spectrum of ZnO nanoparticles in the presence of ZnO-binding $\beta$-annulus peptide 1 exhibited an enhanced emission peak at $410 \mathrm{~nm}$, and the peak further increased in intensity after $24 \mathrm{~h}$. The addition of ZnO-binding peptide 3 to the aqueous dispersion of $\mathrm{ZnO}$ nanoparticles also resulted in an enhanced emission peak at $410 \mathrm{~nm}$, although the intensity was lower than that in the case of peptide $\mathbf{1}$. Such enhancement of blue-violet emission has been also reported by Chang et al. [60], who attributed the enhancement to the electronic passivation effect caused by polyaniline modification of the $\mathrm{ZnO}$ surface. Therefore, the enhanced intensity of the emission peak at $410 \mathrm{~nm}$ shown in Figure 7 is reasonably ascribed to the electronic passivation effect caused by interaction between the ZnO-binding peptide and the $\mathrm{ZnO}$ surface. In contrast, the fluorescence spectrum of $\mathrm{ZnO}$ nanoparticles in the presence of $\beta$-annulus peptide $\mathbf{2}$ exhibited an only slightly enhanced emission peak at $410 \mathrm{~nm}$, which indicates less interaction between the peptide and $\mathrm{ZnO}$ surface. These results suggest that $\mathrm{ZnO}$ nanoparticles were included in the virus-like nanocapsules via interaction between $\mathrm{ZnO}$-binding sequence HCVAHR and $\mathrm{ZnO}$ nanoparticles.

Figure 7. Fluorescence spectra of (black) $\mathrm{ZnO}$ nanoparticles, (blue) a mixture of $\mathrm{ZnO}$ nanoparticles and peptide 1, (red) a mixture of $\mathrm{ZnO}$ nanoparticles and peptide 2 and (green) a mixture of $\mathrm{ZnO}$ nanoparticles and peptide 3 at $[\mathrm{ZnO}]=0.1 \mathrm{mM}$ and [peptide] $=0.1 \mathrm{mM}$ in $10 \mathrm{mM}$ Tris-HCl buffer $\left(\mathrm{pH} \mathrm{7.4)}\right.$ at $25{ }^{\circ} \mathrm{C}$; (a) immediately after preparation and (b) after $24 \mathrm{~h}$. Excitation wavelength: $340 \mathrm{~nm}$.

a

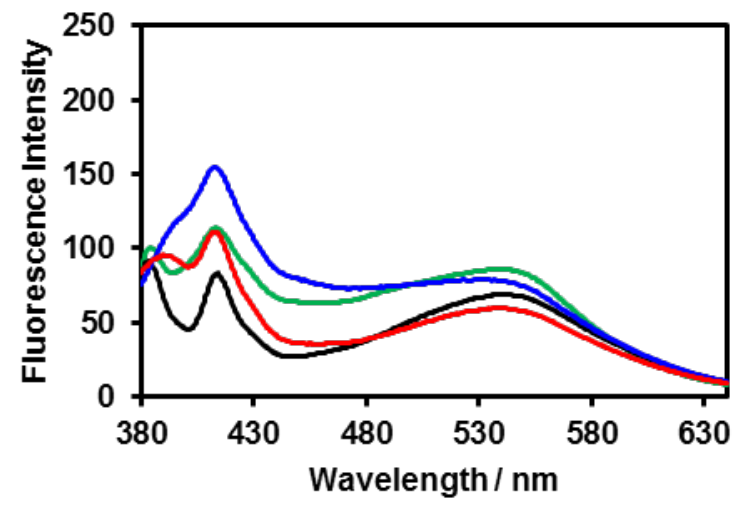

b

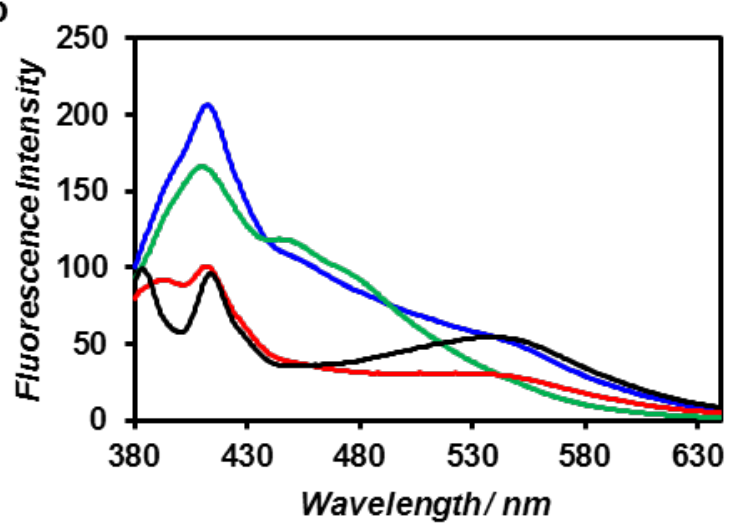

\section{Experimental Section}

\subsection{General}

Reagents were obtained from a commercial source and used without further purification. Reversed-phase HPLC was performed at ambient temperature on a Shimadzu LC-6AD liquid chromatograph equipped with a UV-Vis detector (220 nm, Shimadzu SPD-20A, Sgimadzu Co., Kyoto, Japan) and GL Science Inertsil WP300 C18 (4.6 mm × $250 \mathrm{~mm}$ and $20 \mathrm{~mm} \times 250 \mathrm{~mm})$ columns. MALDI-TOF mass spectra were obtained on an Autoflex II (Bruker Daltonics, Billerica, MA, USA) spectrometer under the linear/positive mode with $\alpha$-cyano-4-hydroxy cinnamic acid ( $\alpha$-CHCA) and dithranol as the matrix. UV-Vis spectra were recorded at $25{ }^{\circ} \mathrm{C}$ using a JASCO V-630 spectrophotometer (Jasco Co., Tokyo, Japan). Fluorescence spectra were measured with excitation at $340 \mathrm{~nm}$ at $25{ }^{\circ} \mathrm{C}$ using a JASCO FP-8200 spectrophotometer. 


\subsection{Syntheses of Peptides}

ZnO-binding $\beta$-annulus peptide (1): The peptide H-His(Trt)-Cys(Trt)-Val-Ala-His(Trt)Arg(Pbf)-Gly-Gly-Gly-Ile-Asn(Trt)-His-(Trt)-Val-Gly-Gly-Thr(tBu)-Gly-Gly-Ala-Ile-Met-Ala-Pro-ValAla-Val-Thr(tBu)-Arg(pbf)-Gln(Trt)-Leu-Val-Gly-Ser(tBu)-Alko-PEG resin was synthesized on Fmoc-Ser(tBu)-Alko-PEG resin (Watanabe Chemical Ind., Ltd., Hiroshima, Japan, $0.21 \mathrm{mmol} / \mathrm{g}$ ) using Fmoc-based coupling reactions (4 equivalent Fmoc amino acids). Solutions of (1-cyano-2-ethoxy-2oxoethylidenaminooxy)dimethylamino-morpholino-carbenium hexafluorophosphate (COMU) and diisopropylamine in $\mathrm{N}$-methylpyrrolidone (NMP) were used as coupling reagents. A solution of $20 \%$ piperidine in $N, N$-dimethylformamide (DMF) was used for Fmoc deprotection. The progress of the coupling reaction and Fmoc deprotection was confirmed using TNBS (2,4,6-trinitrobenzene sulfonic acid) and the Chloranil Test Kit (Tokyo Chemical Industry Co., Ltd., Tokyo, Japan). The peptidyl resin was washed with NMP. The peptide was deprotected and cleaved from the resin by treatment with a mixture of trifluoroacetic acid (TFA)/thioanisole/water/1,2-ethanedithiol/triisopropylsilane = 8.15/0.5/0.5/0.25/0.1 at room temperature for $3 \mathrm{~h}$. The reaction mixture was filtered to remove the resin, and the filtrate was concentrated under vacuum. The peptide was precipitated by adding methyl tert-butyl ether (MTBE) to the residue, and the supernatant was decanted. After the washing with MTBE was repeated three times, the precipitated peptide was dried under vacuum. The crude product was purified by reverse-phase HPLC (RP-HPLC, Inertsil WP300 C18, GL Science Inc., Tokyo, Japan), eluting with a linear gradient of $\mathrm{CH}_{3} \mathrm{CN} /$ water containing 0.1\% TFA (23.5/76.5 to 25.5/74.5 over $100 \mathrm{~min}$ ). The fraction containing the desired peptide was lyophilized to give $6.2 \mathrm{mg}$ of a flocculent solid (6.2\% yield). MALDI-TOF-MS (matrix: $\alpha$-CHCA): $m / z=3181[\mathrm{M}]^{+}$.

$\beta$-Annulus peptide (2): 2 was synthesized according to the previously reported procedure [47]. MALDI-TOF-MS (matrix: $\alpha$-CHCA): $m / z=2305[\mathrm{M}+\mathrm{H}]^{+}$.

ZnO-binding peptide (3): $\mathbf{3}$ was synthesized using a procedure similar to that described for $\mathbf{1}$. The isolated yield was 14.3\%. MALDI-TOF-MS (matrix: dithranol): $\mathrm{m} / \mathrm{z}=916[\mathrm{M}+\mathrm{Na}]^{+}$.

\subsection{Syntheses of $\mathrm{ZnO}$ Nanoparticle}

$\mathrm{ZnO}$ nanoparticles were synthesized according to a literature method [55]. A solution of $0.1 \mathrm{M}$ aqueous $\mathrm{NH}_{3}(0.75 \mathrm{~mL})$ was added to a $0.1 \mathrm{M}$ aqueous solution of $\mathrm{Zn}\left(\mathrm{NO}_{3}\right)_{2} \cdot 6 \mathrm{H}_{2} \mathrm{O}(0.75 \mathrm{~mL})$. The mixture was stirred for $1 \mathrm{~min}$ and then incubated at room temperature for $5 \mathrm{~min}$. The obtained $\mathrm{Zn}(\mathrm{OH})_{2}$ precipitate was separated by centrifugation at $10,000 \mathrm{rpm}$ for $1 \mathrm{~min}$. After the obtained precipitate was washed with water two times, the coexisting ammonium ions and nitrate ions in the precipitate were removed. The $\mathrm{Zn}(\mathrm{OH})_{2}$ precipitate was dispersed in $0.05 \mathrm{M}$ solution of $\mathrm{Zn}\left(\mathrm{NO}_{3}\right)_{2} \cdot 6 \mathrm{H}_{2} \mathrm{O}$ in ethylene glycol $(0.75 \mathrm{~mL})$, and the dispersion was subsequently heated at $35{ }^{\circ} \mathrm{C}$ for $1 \mathrm{~h}$. After the heating process, $\mathrm{ZnO}$ particles were separated by the addition of $0.1 \mathrm{M}$ aqueous $\mathrm{NH}_{3}(0.75 \mathrm{~mL})$ to the sol. The obtained precipitate was then separated by centrifugation at 10,000 rpm for $1 \mathrm{~min}$, washed with water two times and dried at $75{ }^{\circ} \mathrm{C}$ for $12 \mathrm{~h}$. The isolated yield was $2.8 \mathrm{mg}$ (44\%). 


\subsection{Inclusion of $\mathrm{ZnO}$ Nanoparticles into Peptide Nanocapsules}

An aqueous solution of ZnO-binding $\beta$-annulus peptide $1(1 \mathrm{mM}, 20 \mu \mathrm{L})$ was dried in vacuo. An aqueous dispersion of $\mathrm{ZnO}$ nanoparticles $([\mathrm{ZnO}]=0.1 \mathrm{mM}, 0.2 \mathrm{~mL})$ in $10 \mathrm{mM}$ Tris-HCl buffer $(\mathrm{pH} 7.4)$ was added to the dried peptide $\mathbf{1}$, and the mixture was incubated for $10 \mathrm{~min}$ at room temperature.

\subsection{Synthesis of ZnO Nanoparticles in the Presence of Peptide 1}

The $\mathrm{Zn}(\mathrm{OH})_{2}$ precipitate was prepared using the same procedure described in Section 3.3. The precipitate was separated by centrifugation at 10,000 rpm for $1 \mathrm{~min}$ and washed with water two times. The $\mathrm{Zn}(\mathrm{OH})_{2}$ precipitate was dispersed in a $0.05 \mathrm{M}$ aqueous solution of $\mathrm{Zn}\left(\mathrm{NO}_{3}\right)_{2} \cdot 6 \mathrm{H}_{2} \mathrm{O}(7.5 \mathrm{~mL})$. An aliquot $(20 \mu \mathrm{L})$ of the dispersion was added to dried peptide 1 ( $2 \mathrm{nmol}$ ), and the dispersion ([peptide] $=1.0 \mathrm{mM}$ ) was subsequently heated at $35^{\circ} \mathrm{C}$ for $1 \mathrm{~h}$. After the heating process, ZnO particles were separated by adding $0.1 \mathrm{M}$ aqueous $\mathrm{NH}_{3}(0.75 \mathrm{~mL})$ to the sol. The obtained precipitate was then separated by centrifugation at 10,000 rpm for $1 \mathrm{~min}$, washed with water two times and dried in vacuo.

\subsection{Dynamic Light Scattering (DLS) Measurements}

DLS was measured with a Zetasizer NanoZS (MALVERN Instruments Ltd., Worcestershire, UK) instrument at $25^{\circ} \mathrm{C}$ using an incident He-Ne laser $(633 \mathrm{~nm})$. The correlation time of scattered light intensity $G(\tau)$ was measured several times, and their averaged data were fitted to Equation (2):

$$
G(\tau)=B+\tau) \exp \left(-2 q^{2} D\right.
$$

where $B$ is the baseline, $A$ is the amplitude, $q$ is the scattering vector, $\tau$ is the delay time and $D$ is the diffusion coefficient. The hydrodynamic radius $\left(R_{H}\right)$ of the scattering particles was calculated by the Stokes-Einstein equation (Equation (3)):

$$
R_{H}=\frac{\kappa_{B} T}{6 \pi \eta D}
$$

where $\eta$ is solvent viscosity, $k_{B}$ is Boltzmann's constant and $T$ denotes the absolute temperature.

\subsection{Transmission Electron Microscopy (TEM)}

An aliquot $(5 \mu \mathrm{L})$ of each sample solution was applied to a carbon-coated grid (C-SMART Hydrophilic TEM grid, ALLANCE Biosystems, Osaka, Japan), left for $60 \mathrm{~s}$ and then removed. The grid was subsequently dried in vacuo. In the case of peptide samples, a drop of $2 \mathrm{wt} \%$ aqueous sodium phosphotungstate was placed on each of the grids and dried in vacuo. The sample-loaded carbon-coated grids were subjected to TEM observation (JEOL JEM 1400 Plus, JEOL Ltd., Tokyo, Japan) using an acceleration voltage of $80 \mathrm{kV}$. The $\mathrm{ZnO}$ nanoparticles were observed without the use of a stain.

\section{Conclusions}

We have demonstrated that a $\beta$-annulus peptide having a $\mathrm{ZnO}$-binding sequence self-assembled into the virus-like peptide nanocapsules and included several $\mathrm{ZnO}$ nanoparticles inside. ZnO nanoparticles included in the nanocapsules were relatively stable in water, even though $\mathrm{ZnO}$ nanoparticles typically 
tend to aggregates under such conditions. ZnO nanoparticles formed larger aggregates in the presence of $\beta$-annulus peptide or $\mathrm{ZnO}$-binding peptide. The fluorescence spectra of $\mathrm{ZnO}$ nanoparticles in the presence of $\mathrm{ZnO}$-binding $\beta$-annulus peptide revealed that $\mathrm{ZnO}$ nanoparticles interact with the peptides. We envisage that the artificial virus-like nanocapsules can include various inorganic materials through proper modification of their interior. We will extend the present molecular design to various peptide-inorganic fusion materials in future work.

\section{Acknowledgments}

This research was supported by a Grant-in-Aid for Scientific Research in the Innovative Areas of "Fusion Materials" (No. 2206) from the Ministry of Education, Science, Sports and Culture of Japan (MEXT).

\section{Author Contributions}

Seiya Fujita: experimental design, all experimental work and writing. Kazunori Matsuura: concept, experimental design and writing.

\section{Conflicts of Interest}

The authors declare no conflict of interest.

\section{References and Notes}

1. Alivisatos, A.P. Perspectives on the physical chemistry of semiconductor nanocrystals. J. Phys. Chem. 1996, 100, 13226-13239.

2. Trindade, T.; O’Brien, P.; Pickett, N.L. Nanocrystalline semiconductors: Synthesis, properties, and perspectives. Chem. Mater. 2001, 13, 3843-3858.

3. Gao, X.H.; Cui, Y.Y.; Levenson, R.M.; Chung, L.W.K.; Nie, S.M. In vivo cancer targeting and imaging with semiconductor quantum dots. Nat. Biotechnol. 2004, 22, 969-976.

4. Biju, V.; Itoh, T.; Anas, A.; Sujith, A.; Ishikawa, M. Semiconductor quantum dots and metal nanoparticles: Syntheses, optical properties, and biological applications. Anal. Bioanal. Chem. 2008, 391, 2469-2495.

5. Smith, A.M.; Duan, H.W.; Mohs, A.M.; Nie, S.M. Bioconjugated quantum dots for in vivo molecular and cellular imaging. Adv. Drug Deliv. Rev. 2008, 60, 1226-1240.

6. Zrazhevskiy, P.; Sena, M.; Gao, X.H. Designing multifunctional quantum dots for bioimaging, detection, and drug delivery. Chem. Soc. Rev. 2010, 39, 4326-4354.

7. Jamieson, T.; Bakhshi, R.; Petrova, D.; Pocock, R.; Imani, M.; Seifalian, A.M. Biological applications of quantum dots. Biomaterials 2007, 28, 4717-4732.

8. Van Dijken, A.; Meulenkamp, E.A.; Vanmaekelbergh, D.; Meijerink, A. The kinetics of the radiative and nonradiative processes in nanocrystalline $\mathrm{ZnO}$ particles upon photoexcitation. J. Phys. Chem. B 2000, 104, 1715-1723.

9. Liu, M.; Kitai, A.H.; Mascher, P. Point defects and luminescence centres in zinc oxide and zinc oxide doped with manganese. J. Lumin. 1992, 54, 35-42. 
10. Wen, F.S.; Li, W.L.; Moon, J.H.; Kim, J.H. Hydrothermal synthesis of ZnO: Zn with green emission at low temperature with reduction process. Solid State Commun. 2005, 135, 34-37.

11. Abdullah, M.; Shibamoto, S.; Okuyama, K. Synthesis of $\mathrm{ZnO} / \mathrm{SiO}_{2}$ nanocomposites emitting specific luminescence colors. Opt. Mater. 2004, 26, 95-100.

12. Xiong, H.M.; Xu, Y.; Ren, O.G.; Xia, Y.Y. Stable aqueous ZnO@polymer core-shell nanoparticles with tunable photoluminescence and their application in cell imaging. J. Am. Chem. Soc. 2008, 130, 7522-7523.

13. Hines, P.; Hines, D.A.; Kamat, P.V. Recent advances in quantum dot surface chemistry. ACS Appl. Mater. Interfaces 2014, 6, 3041-3057.

14. Harrison, P.M.; Arosio, P. Ferritins: Molecular properties, iron storage function and cellular regulation. Biochim. Biophys. Acta 1996, 1275, 161-203.

15. Massover, W.H. Ultrastructure of ferritin and apoferritin: A review. Micron 1993, 24, 389-437.

16. Wong, K.K.W.; Mann, S. Small-scale structures in biomineralisation and biomimetic materials chemistry. Curr. Opin. Colloid Interface Sci. 1998, 3, 63-68.

17. Ueno, T.; Suzuki, M.; Goto, T.; Matsumoto, T.; Nagayama, K.; Watanabe, Y. Size-selective olefin hydrogenation by a Pd nanocluster provided in an apo-ferritin cage. Angew. Chem. Int. Ed. 2004, 43, 2527-2530.

18. Galvez, N.; Sanchez, P.; Dominguez-Vera, J.M. Preparation of $\mathrm{Cu}$ and CuFe prussian blue derivative nanoparticles using the apoferritin cavity as nanoreactor. Dalton Trans. 2005, 15, 2492-2494.

19. Galvez, N.; Sanchez, P.; Dominguez-Vera, J.M.; Soriano-Portillo, A.; Clemente-Leon, M.; Coronado, E. Apoferritin-encapsulated Ni and Co superparamagnetic nanoparticles. J. Mater. Chem. 2006, 16, 2757-2761.

20. Zhang, L.; Swift, J.; Butts, C.A.; Yerubandi, V.; Dmochowski, I.J. Structure and activity of apoferritin-stabilized gold nanoparticles. Inorg. Chem. 2007, 101, 1719-1729.

21. Wong, K.K.W.; Mann, S. Biomimetic synthesis of cadmium sulfide-ferritin nanocomposites. Adv. Mater. 1996, 8, 928-932.

22. Yamashita, I.; Hayashi, J.; Hara, M. Bio-template synthesis of uniform CdSe nanoparticles using cage-shaped protein, apoferritin. Chem. Lett. 2004, 33, 1158-1159.

23. Iwahori, K.; Morioka, T.; Yamashita, I. The optimization of CdSe nanoparticles synthesis in the apoferritin cavity. Phys. Stat. Sol. 2006, 203, 2658-2661.

24. Iwahori, K.; Yoshizawa, K.; Muraoka, M.; Yamashita, I. Fabrication of ZnSe nanoparticles in the apoferritin cavity by designing a slow chemical reaction system. Inorg. Chem. 2005, 44, 6393-6400.

25. Yoshizawa, K.; Iwahori, K.; Sugimoto, K.; Yamashita, I. Fabrication of gold sulfide nanoparticles using the protein cage of apoferritin. Chem. Lett. 2006, 35, 1192-1193.

26. Hennequin, B.; Turyanska, L.; Ben, T.; Beltran, A.M.; Molina, S.I.; Li, M.; Mann, S.; Patane, A.; Thomas, N.R. Aqueous near-infrared fluorescent composites based on apoferritin-encapsulated PbS quantum dots. Adv. Mater. 2008, 20, 3592-3596.

27. Suzumoto, Y.; Okuda, M.; Yamashita, I. Fabrication of zinc oxide semiconductor nanoparticles in the apoferritin cavity. Cryst. Grow. Des. 2012, 12, 4130-4134.

28. Branden, C.; Tooze, J. Introduction to Protein Structure, 2nd ed.; Garland Publishing: New York, NY, USA, 1999. 
29. Douglas, T.; Young, M. Viruses: Making friends with old foes. Science 2006, 312, 873-875.

30. Steinmetz, N.F.; Evans, D.J. Utilisation of plant viruses in bionanotechnology. Org. Biomol. Chem. 2007, 5, 2891-2902.

31. Steinmetz, N.F.; Lin, T.; Lomonossoff, G.P.; Johnson, J.E. Structure-based engineering of an icosahedral virus for nanomedicine and nanotechnology. Viruses Nanotechnol. 2009, 327, 23-58.

32. Bronstein, L.M. Virus-based nanoparticles with inorganic cargo: What does the future hold? Small 2011, 7, 1609-1618.

33. Gillitzer, E.; Willits, D.; Young, M.; Douglas, T. Chemical modification of a viral cage for multivalent presentation. Chem. Commun. 2002, 20, 2390-2391.

34. Loo, L.; Guenther, R.H.; Lommel, S.A.; Franzen, S. Infusion of dye molecules into red clover necrotic mosaic virus. Chem. Commun. 2008, 88-90.

35. Ren, Y.; Wong, S.M.; Lim, L.-Y. Folic acid-conjugated protein cages of a plant virus: Anovel deliveryplatform for doxorubicin. Bioconjug. Chem. 2007, 18, 836-843.

36. Comellas-Aragonès, M.; Engelkamp, H.; Claessen, V.I.; Sommerdijik, N.A.J.M.; Rowan, A.E.; Christianen, P.C.M.; Maan, J.C.; Verduin, B.J.M.; Cornelissen, J.J.L.M.; Nolte, R.J.M. A virus-based single-enzyme nanoreactor. Nat. Nanotechnol. 2007, 2, 635-639.

37. Minten, I.J.; Hendriks, L.J.A.; Nolte, R.J.M.; Cornelissen, J.J.L.M. Controlled encapsulation of multiple proteins in virus capsids. J. Am. Chem. Soc. 2009, 131, 17771-17773.

38. Comellas-Aragonès, M.; de la Escosura, A.; Dirks, A.T.J.; van der Ham, A.; Fusté-Cuñé, A.; Cornelissen, J.J.L.M.; Nolte, R.J.M. Controlled integration of polymers into viral capsids. Biomacromolecules 2009, 10, 3141-3147.

39. Chen, C.; Kwak, E.S.; Stein, B.; Kao, C.C.; Dragnea, B. Packaging of gold particles in viral capsids. J. Nanosci. Nanotechnol. 2005, 5, 2029-2033.

40. Chen, C.; Daniel, M.C.; Quinkert, Z.T.; De, M.; Stein, B.; Bowman, V.D.; Chipman, P.R.; Rotello, V.M.; Kao, C.C.; Dragnea, B. Nanoparticle-templated assembly of viral protein cages. Nano Lett. 2006, 6, 611-615.

41. Loo, L.; Guenther, R.H.; Basnayake, V.R.; Lommel, S.A.; Franzen, S. Controlled encapsidation of gold nanoparticles by a viral protein shell. J. Am. Chem. Soc. 2006, 128, 4502-4503.

42. Huang, X.L.; Bronstein, L.M.; Retrum, J.; Dufort, C.; Tsvetkova, I.; Aniagyei, S.; Stein, B.; Stucky, G.; McKenna, B.; Remmes, N.; et al. Self-assembled virus-like particles with magnetic cores. Nano Lett. 2007, 7, 2407-2416.

43. Gao, D.; Zhang, Z.P.; Li, F.; Men, D.; Deng, J.Y.; Wei, H.P.; Zhang, X.E.; Cui, Z.Q. Quantum dot-induced viral capsid assembling in dissociation buffer. Int. J. Nanomed. 2013, 8, 2119-2128.

44. Dixit, S.K.; Goicochea, N.L.; Daniel, M.C.; Murali, A.; Bronstein, L.; De, M.; Stein, B.; Rotello, V.M.; Kao, C.C.; Dragnea, B. Quantum dot encapsulation in viral capsids. Nano Lett. 2006, 6, 1993-1999.

45. Matsuurua, K. Rational design of self-assembled proteins and peptides for nano- and micro-sized architectures. RSC Adv. 2014, 4, 2942-2953.

46. Ramakers, B.E.I.; van Hest, J.C.M.; Lowik, D. Molecular tools for the construction of peptide-based materials. Chem. Soc. Rev. 2014, 43, 2743-2756.

47. Matsuura, K.; Watanabe, K.; Matsuzaki, T.; Sakurai, K.; Kimizuka, N. Self-assembled synthetic viral capsids from a 24-mer viral peptide fragment. Angew. Chem. Int. Ed. 2010, 49, 9662-9665. 
48. Matsuura, K. Construction of spherical virus-inspired peptide nanoassemblies. Polym. J. 2012, 44, 469-474.

49. Matsuura, K.; Watanabe, K.; Matsushita, Y.; Kimizuka, N. Guest-binding behavior of peptide nanocapsules self-assembled from viral peptide fragments. Polym. J. 2013, 45, 529-534.

50. Thai, C.K.; Dai, H.X.; Sastry, M.S.R.; Sarikaya, M.; Schwartz, D.T.; Baneyx, F. Identification and characterization of $\mathrm{Cu}_{2} \mathrm{O}$ - and $\mathrm{ZnO}$-binding polypeptides by Escherichia coli cell surface display: Toward an understanding of metal oxide binding. Biotechnol. Bioeng. 2004, 87, 129-137.

51. Kjaergaard, K.; Sorensen, J.K.; Schembri, M.A.; Klemm, P. Sequestration of zinc oxide by fimbrial designer chelators. Appl. Environ. Microbiol. 2000, 66, 10-14.

52. Golec, P.; Karczewska-Golec, J.; Los, M.; Wegrzyn, G. Novel ZnO-binding peptides obtained by the screening of a phage display peptide library. J. Nanopart. Res. 2012, 14, 1218-1223.

53. Umetsu, M.; Mizuta, M.; Tsumoto, K.; Ohara, S.; Takami, S.; Watanabe, H.; Kumagai, I.; Adschiri, T. Bioassisted room-temperature immobilization and mineralization of zinc oxide-The structural ordering of $\mathrm{ZnO}$ nanoparticles into a flower-type morphology. Adv. Mater. 2005, 17, 2571-2575.

54. Okochi, M.; Sugita, T.; Furusawa, S.; Umetsu, M.; Adschiri, T.; Honda, H. Peptide array-based characterization and design of ZnO-high affinity peptides. Biotechnol. Bioeng. 2010, 106, 845-851.

55. HCVAHR sequence might be adsorbed on $\mathrm{ZnO}$ surface through coordination bonds with His and Cys residues.

56. Uekawa, N.; Yamazaki, A.; Ishii, S.; Kojima, T.; Kakegawa, K. Synthesis of a stable sol of ZnO nanoparticles by low-temperature heating of $\mathrm{Zn}(\mathrm{OH})_{2}$ in ethylene glycol containing $\mathrm{Zn}^{2+}$ ions. J. Ceram. Soc. Jpn. 2010, 118, 96-101.

57. Meulenkamp, E.A. Synthesis and growth of ZnO nanoparticles. J. Phys. Chem. B 1998, 102, 5566-5572.

58. Liang, Z.W.; Yu, X.A.; Lei, B.F.; Liu, P.Y.; Mai, W.J. Novel blue-violet photoluminescence from sputtered ZnO thin films. J. Alloys Compd. 2011, 509, 5437-5440.

59. Hu, Y.; Chen, H.J. Preparation and characterization of nanocrystalline ZnO particles from a hydrothermal process. J. Nanopart. Res. 2008, 10, 401-407.

60. Chang, M.; Cao, X.L.; Zeng, H.; Zhang, L. Enhancement of the ultraviolet emission of ZnO nanostructures by polyaniline modification. Chem. Phys. Lett. 2007, 446, 370-373.

(C) 2014 by the authors; licensee MDPI, Basel, Switzerland. This article is an open access article distributed under the terms and conditions of the Creative Commons Attribution license (http://creativecommons.org/licenses/by/3.0/). 